\title{
Factors Affecting University Students in Shoes Selection: Turkey Example
}

\author{
Assist. Prof. Hatice Harmankaya \\ Dr. Selda Guzel \\ Research Assist. Asuman Yilmaz Filiz \\ Selçuk University, Art and Design Faculty, Fashion Design Program
}

\author{
Doi:10.5901/mjss.2013.v4n10p394
}

\begin{abstract}
With the born of human, many physiological needs have come out and human being has looked for the solutions to be protected from negative conditions of the environment. One of them is shoes which are developed to protect feet. Shoes, which are an inseparable part of wearing, have changed in terms of their function, visual dimension and use area until today and shown diversity. This diversity has led people to do preferences in the direction of their savour and needs. The study has been carried out to determine the factors, model and type properties that are paid attention by the university students in shoes selection and use. In the scope of the research, the survey has been applied to the total 300 people randomly selected from students taking education in Konya and Karaman. The data got have been transferred to SPSS package program and findings have been given in tables. In the findings, it is seen that the comfort element and wearing style are big factors in shoes preference. Moreover, it has been detected that flats and rounded-toe shoes are demanded more than others. The research results carry importance for revealing properties young consumers prefer on shoes and for contributing to producers to determine the marketing strategies.
\end{abstract}

Keywords: University students, shoes, shoes preferences, consumer behaviours

\section{Introduction}

Consumption, which is generally described as meeting the needings, is not only an economic issue but also a society aspect that changes by the conditions of the time, takes shape by the social and cultural values which are accepted by different countries and societies (Bocock, 2005: 13). The consumption, as a matter of fact, which can be described in the simplest way as spending the products and services in order to meet the needing of individuals, have become one of the most referenced concept for describing the socio-cultural features of the day and obtained a complex structure after the industrial revolution (Başfırıncı, 2011: 116). Türbal (1997: 108) also described the consumption as directly using the benefits of economic products and affairs in order to meet the needing of people.

Identity, needings and wants, targets of the customers and the questions, who is the decisive authority of purchasing, how to decide, when the people are ready to buy or where they prefer to buy, are the features that shows the consuming habits (Kotler, 2000: 116). Personal, physical and sociologic structure of the consumer affects the selection of product. Needings, age, sex, education, profession, income level, taste, expectancy and price causes difference on consumptions. Age group is also a decisive factor that can define the styles and models which the person will head (Mucuk, 1998:87; Yaylalı vd., 2011:2).

College students create important survey areas in several sectors due to being young customers. It is also known that, especially the individuals in the young ages make a point of being accepted by the public and positively evaluated by the friend zone (Erwin, 2000: 86).

Shoes, creating different options by some reasons such as visuality, functionality, difference in style and variety of usage, have a great importance especially for young customers.

Shoes take place in our lives as a functional accessory which our body can stand straight by and help us to move easily. Shoes, which have been a symbol of statue since the first dates of history, also mean some abstract meanings besides having its aim of use (Çivitçi vd., 2012:101). There are a large variety of shoes today, those have a significant place as an accessory. Newman stated that (2006), all shoes have a story and reflect the statue, sexual identity, ethnic group, religion, profession and also political view. 


\section{Method}

Describing method is used in this study to determine the features that the college students concern on purchasing shoes. The universe of the study consists of college students and samples are 300 students who are randomly chosen from Selçuk University and Karamanoğlu Mehmet Bey University. Related sources are scanned and the developed questionnaire form was used in order to obtain the survey data. Questionnaire form consists of 11 questions. First three questions of the questionnaire are related to the demographic features which define sex, age and income level. Other questions, one of them are 3 point likert scale and the other one is 5 point likert scale, are towards defining the choice of students. Missing or mistaken ones of the questionnaires, obtained from the survey, were selected and not taken into account. Data were analyzed in percentage and results were given in charts.

\section{Findings}

In this chapter, the data obtained from the questionnaires which are made in order to define the factors that affect the selection of shoes of the college students, is given by the graphics.

Women are $\% 53.7$ and men are $\% 46.3$ of the sample group. The age groups of the samples are as followings.

$\% 45.7$ for $21-25, \% 36.7$ for $18-25, \% 12.7$ for $26-30, \% 3.3$ for $31-35$ and $\% 1.7$ for $36-40$. The reason of the age group of 21-25 is the highest that, the samples are choosen form college students. When the income level is examined, $\% 49.32$ of the samples have $251-500$ TRY, $\% 4,3$ of them have 1001 or more TRY.
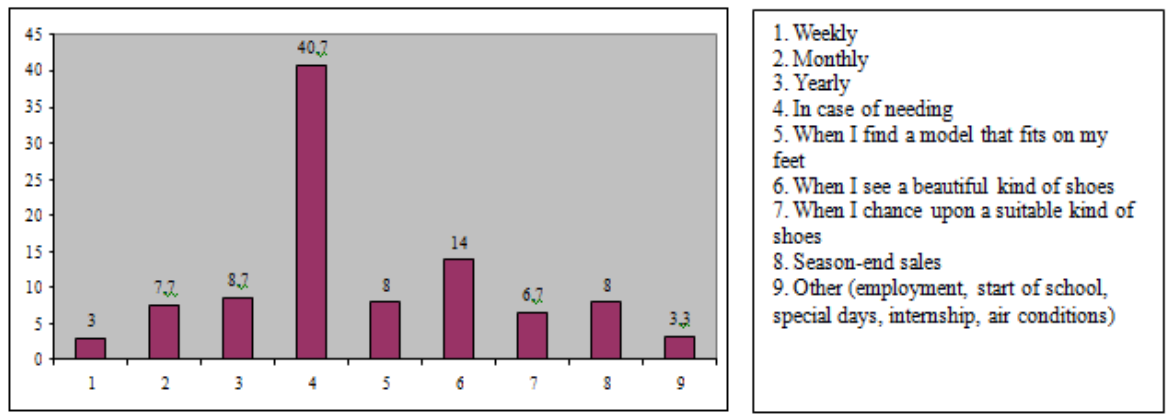

Chart 1. Monthly Shopping Frequency

$\% 40.7$ of college students purchase shoes in case of needing, is observed when the findings of monthly shopping frequency of the college students are examined. In addition to this, $\% 3$ of them buy shoes weekly and $\% 3.3$ of them buy shoes in 'other' (employment, start of school, special days, internship, air conditions) times. Ersoy and colleague (2004) obtained the result in the study and collected the data for college students purchasing shoes in times of $\% 49.6$ when the shoes are old or the students need a pair of new shoes, \% 21.4 start of season or end of season, $\% 20.1$ start of season, $\% 5.8$ season end sale and \% 3.1 both the start of season and when the shoes are old.
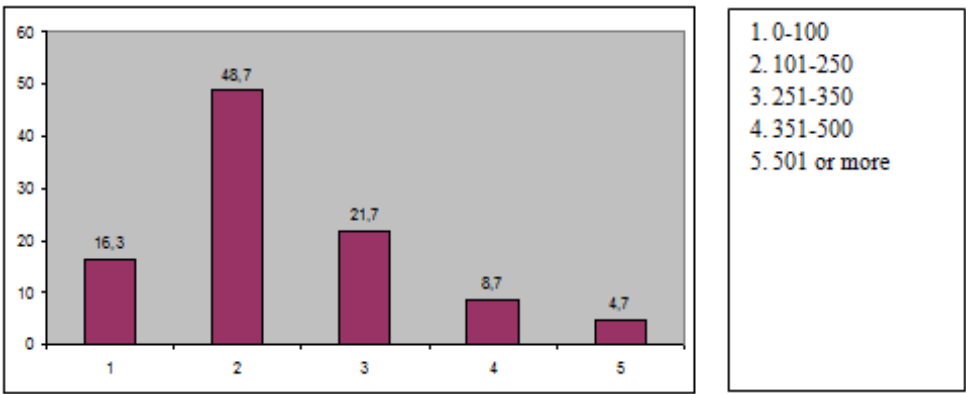

Chart 2. Sum Spent on Shopping

When the amount of purchasing shoes are examined for 1 year term for college students, 101-250 tl interval is observed as the highest rate with $\% 48,7$. Moreover, $\% 4,7$ of college students spent 500 TRY or more and \%8,7 of them spent 351 500 TRY. The effect of socio-economic factors cannot be denied when purchasing clothing. The poeple who have high or medium income level spend for meeting the taste besides the emergency goods while the people who have low income level spend for emergency goods (Akça et al., 2011: 176). 


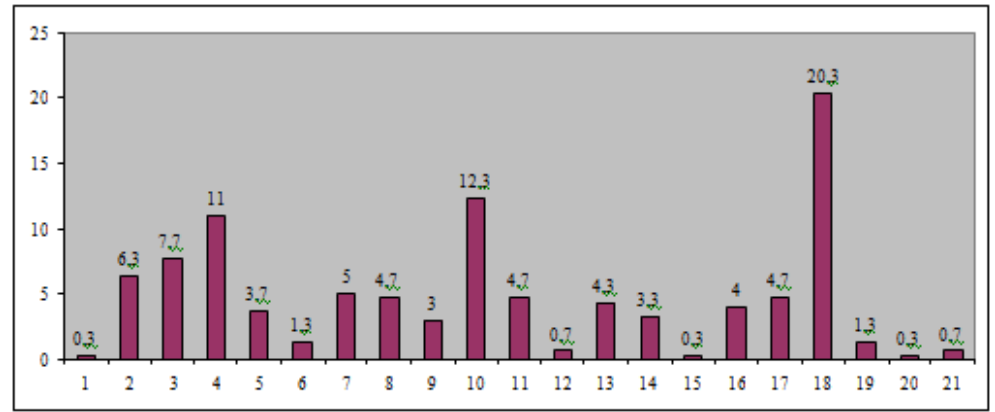

Chart 3. Preferred Type of Shoes

\begin{tabular}{|lll|}
\hline 1. Ballerina & 8. Lace-ups & 15. Francesina \\
2. Stiletto & 9. Booti & 16. Moccasin \\
3. Loafer & 10. Boot & 17. Derby \\
4. Babette & 11. Welly & 18. Trainers \\
5. Sandal & 12. Mule & 19. Platform heeled \\
6. Gladiator & 13. Orthopedic Shoes & 20. Crocs \\
7. Espadrille & 14. Walking Shoes & 21. Slippers \\
& & \\
\hline
\end{tabular}

The choice of shoes of the male and female college students are examined and the highest rate is found as $\% 20.3$ for trainers for both gender. The most important factors of the sneakers emerged as features of non-sweating, suitable for health and durable as a result of the study made by Akkoç and colleagues (2012), concerning the brand loyalty level of college students. Some similar structural features of the sneakers can be shown as a reason for college students. Students gave low rates for the others such as, for ballerina ( $\% 0.3)$, for mule $(\% 0.7)$, for francesine $(\% 0.3)$, for crocs $(\%$ $0.3)$ and for slippers (\% 0.7).
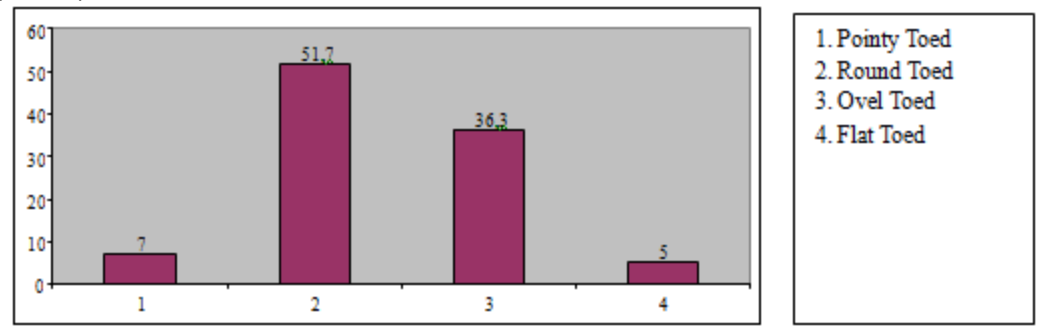

\section{Chart 4. Preferred Toe Shape of Shoes}

The preffered type of toe shape of the shoes are examined and it is found that, round toed shoes are the most preferred shoes among the samples with the rate of $\% 51.7$. The least preferred ones are the flat toed $\% 5$ and pointy toed $\% 7$. This can be concidered as the fashionable shoes affected the choice.
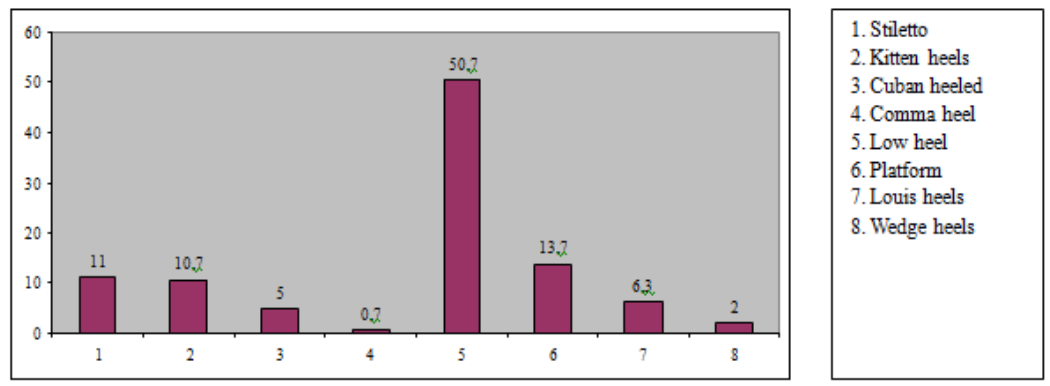

Chart 5. Preferred Type of Heels

When the Chart 5 which shows the heel selection was examined, it can be seen that, $\% 50,7$ of the participants prefer low heel. Comma (\%0.7), wedge (\%2) and Cuban heel (\%5) were rarely preferred by the college students. Furthermore, this result is also affected by the sample group, because almost the half of this group consists of male students. Shoes especially should not limit the moves in daily activities. Therefore, heeled shoes may cause some problems. Women limit their physical strength by wearing these kinds of shoes, because it is quite difficult to run, walk or jump with the high heeled shoes (Kula Demir, 2005: 244). 

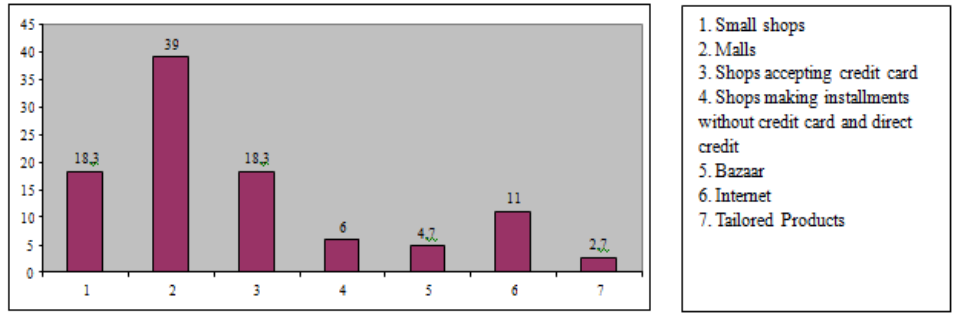

Chart 6. The Places Where the Shoes are Bought

Malls (\%39) were observed having the highest rate when the Chart 6, showing the shopping places of college students, was examined. Little stores (\%18.3) and the shops which accept credit card (\%18.3) were equally selected for purchasing shoes, as a result of this studyPlaces where are the goods are exhibited are elements that define the process of shopping, while ads and commercials and the fashion affect the purchasing behaviour of individuals. The malls in the downtown, which supply the produced goods and services, meet the needing of bazaar for people and become an entertainment zone and a must place for leisure activities (Kaya, 2003; 174). Moreover, shopping malls have some primacy both in giving an ease to the customers and maintaining the stores dynamic. Stores in malls have a synergy even though they are close to each other and thus rivals. This closeness also provides important advantages to the customers. A customer who cannot find the desired good in one store does not look for any other store on the street or in the neighborhood and meets the needing in the same mall (Çakmak, 2012:199).
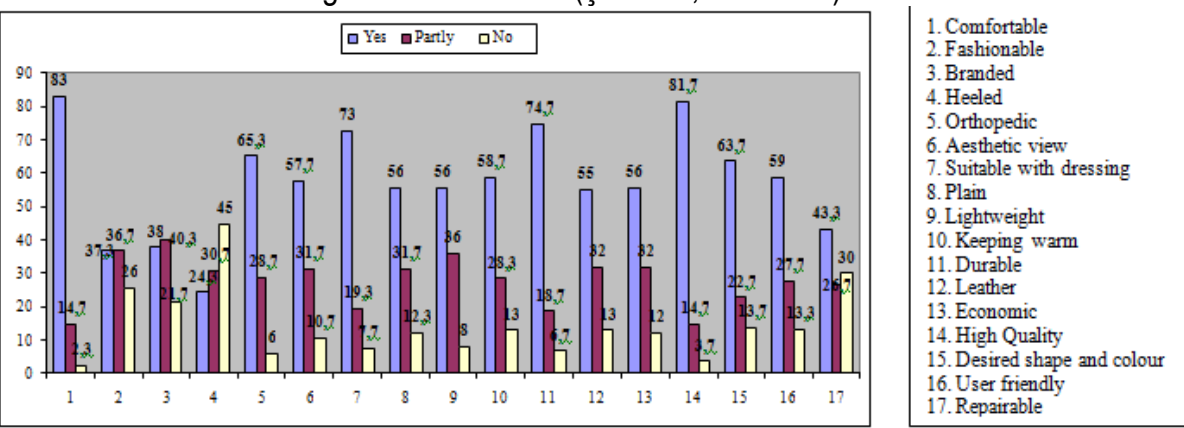

Chart 7. Main Factors on Preferring Shoes

Comfort (\%83) and quality (\%81.7) have great importance for most students when the Chart 7 in which the factors of shoe selection take place was examined. Aktuğlu and Temel (2006) found that result after the study, \%57.3 of participants always mind the brand for shoes and slippers. The factors, which the college students consider for the choice of shoes, vary. It is especially aimed that the comfort is primary for daily conditions and usage. College students should prefer the goods which have informing labels about the material type of clothing and the maintenance and cleaning methods on them. (Ersoy et al., 2004: 10).

Besides these factors, durability $(\% 74,7)$, being suitable for dressing $(\% 73)$, being orthopedic $(\% 65,3)$ and being in the desired shape and colour $(\% 63,7)$ are also playing role on purchasing. The main reason that the college students do not choose a type of shoes is having certain heels (\%45). Furthermore, being repairable (\%30) and being fashionable (\%26) are not the reasons to buy shoes.

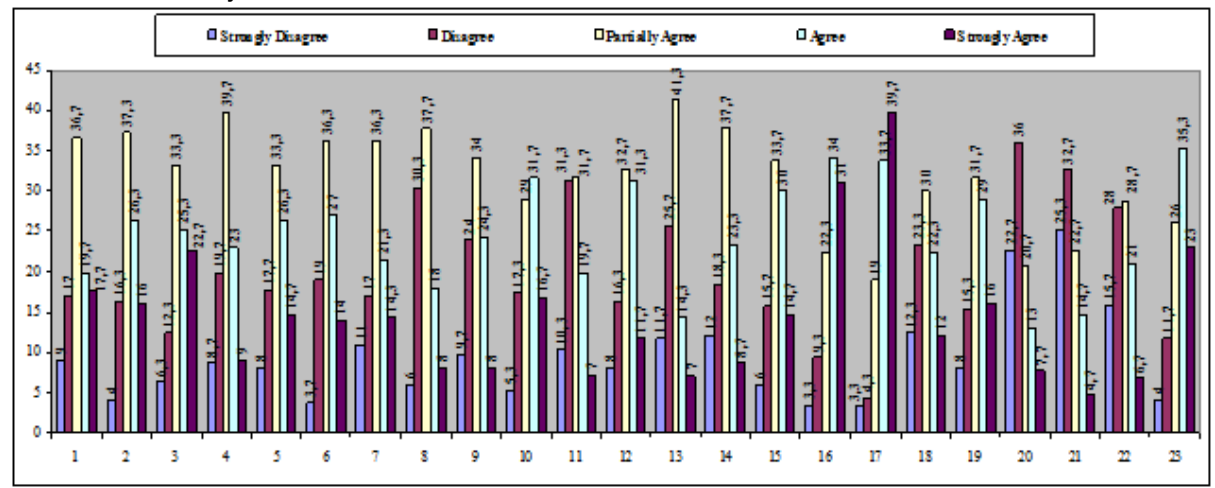


Chart 8. The Factors Affecting the Choice of Shoes

\begin{tabular}{|c|c|}
\hline $\begin{array}{l}\text { 1. What do I wear and I feel good when my shoes are chic } \\
\text { 2. I buy the products having promotions } \\
\text { 3. The brand which I use should have warranty } \\
\text { 4. I prefer cheap shoes, thus I have a large variety of them } \\
\text { 5. I prefer buying expensive shoes and wear it long years } \\
6 \text {. I prefer the brand with the gift promotion } \\
\text { 7. My shoes and my bag should be compatible } \\
\text { 8. I do not trust the new brands } \\
\text { 9. I find foreign brands more qualified } \\
\text { 10. I pruchase after I made a price search on the model of different brands } \\
\text { 11. I am loyal to the shops whereI bought before } \\
\text { 12. I concern on the thoughts of other users when choosing brand } \\
\text { 13. I prefer the goods with high reputation }\end{array}$ & $\begin{array}{l}\text { 14. Well known brands are always trustable } \\
\text { 15. My shoes should be washable } \\
\text { 16. My shoes shouldnotlose its colour and should not be stain } \\
\text { 17. My shoes should not make my feet sweat } \\
\text { 18. I keep an eye on extra laces when I buy lace-up shoes } \\
\text { 19. Lace- up shoes are safer than the others. } \\
\text { 20. I usually prefer velcro shoes } \\
\text { 21. I prefer wooden base } \\
\text { 22. I prefer plastic base } \\
\text { 23. I prefer rubber base }\end{array}$ \\
\hline
\end{tabular}

High popularity (\% 41.3) was emerged as an important factor for the college students when the factors affecting the selection of shoes were examined. In addition to this, non-sweating (\%39.7), colorfast and stainless (\% 31) products have great importance.

It is also seen that, the products which are good in price but surplus $(\% 39.7)$ and the products in price promotion are partially preferred. Velcro fastener (\%36), timber based (\%32.7) and rubber based (\% 28.7) products are rarely preferred according to the results.

\section{Conclusions}

Shoes are important components of dressing which have a large variety and are chosen referring to the different conditions. Shoes are real focus point for the youngs, and are being preferred according to the daily wearing, purpose of use and air conditions. This study is important for determining the choices of college students for the shoemaking sector, producters developing broad marketing strategies through the preferred types of shoes, designers designing new models for mostly preferred kind of shoes and making it various.

It is resulted that college students usually purchase shoes in the times of need, and sneakers are highly preferred by both male and female students. It is obvious that the non-heeled shoes are mostly preferred when the daily conditions are concerned. Being compatible with the dresses is also another factor for the shoes. Some other important reasons are being comfortable, orthopedic and having high quality.

Visual manner is also significant besides the comfort and health for the college students. Other reasons for choice are having ease on daily usage, being compatible with the dressing and reflecting the own wearing style. New marketing strategies can be developed by concerning some factors about the choice of college students, and some differences on designs can be made.

\section{References}

Akkoç, Feden, vd., (2012). "Uşak Üniversitesi Öğrencilerinin Spor Ayakkabı Marka Sadakatlerini Değerlendirmeye Yönelik Bir Uygulama”, Uşak Üniversitesi Sosyal Bilimler Dergisi, 5/3, 197-213

Akça, Raziye, (2011). "15-18 Yaş Grubu Ergenlerde Giysi Seçimini Etkileyen Faktörler", e-Journal of New World Sciences Academy, 175-186.

Aktuğlu, Işıl, Karpat, Temel, Ayşen, (2006). Tüketiciler Markaları Nasıl Tercih Ediyor? ( Kamu Sektörü Çalışanlarının Giysi Markalarını Tercihini Etkileyen Faktörlere Yönelik Bir Araştırma), Selçuk Üniversitesi Sosyal Bilimler Enstitüsü Dergisi, Sayı: 15, 43-59

Başfırıncı, Çiğdem, (2011). "Modern Türk Tüketim Kültürüne Yönelik Bir Araştırma", Millî Folklor, Sayı: 91, 115-129

Bocock, Robert, (2005). Tüketim, Çev. Irem Kutluk, Dost Kitabevi, Ankara.

Çakmak, Ali, çağlar, (2012). Ziyaretçilerin Alışveriş Merkezlerini Tercih Etme Nedenlerinin Araştıııması: Karabük Şehir Merkezinde Bir Uygulama, Niğde Üniversitesi İiBF Dergisi, 2012, Cilt: 5, Sayı: 2, 195-215

Çivitçi, Şule, vd., (2012). Giysi Seçimi, Açıköğretim Fakültesi Yayını, Eskişehir.

Érsoy, Ali, Fuat, vd., (2004). "Üniversite Öğrencilerinin Giysi ve Ayakkabı Tüketiminde Markaya Yönelik Davranış ve Tercihleri", Gazi Üniversitesi Endüstriyel Sanatlar Eğitim Fakültesi Dergisi, 7-14, 1-12.

Erwin, Phil, (2000). Çocuklukta ve Ergenlikte Arkadaşlık, (Çev. Akınhay, Osman), Alfa Yayıları, Birinci Basım, İstanbul.

Kaya, Kamil, (2003). Türk Toplumunun Yaşama Tarzı, Fakülte Kitabevi, Isparta.

Kula Demir, Nesrin (2005). "Kimliklere Ayna Tutan Reklam Fotoğrafları", Manas Üniversitesi Sosyal Bilimler Dergisi, Sayı 14, Bişkek, $237-251$.

Kotler, Philip, (2000). Kotler ve Pazarlama, Çev. Ayşe Özyağcılar, Sistem Yayınclık, İstanbul.

Mucuk, İsmet, (1998). Pazarlama İlkeleri, 10. Baskı, Türkmen Kitabevi, İstanbul.

Newman, Cathy, (2006). "The Joy of Shoes", National Geographic Magazine, 74, 93

Türkbal, Aydın, (1997), Mikroiktisat, 3. Bask., Filiz Kitabevi, İstanbul.

Yaylalı, Muammer, (2011). "Selçuk Üniversitesi Seydişehir Meslek Yüksekokulu Öğrencilerinin Gelir-Harcama İlişkisi ve Meslek Yüksekokulunun İlçe Ekonomisine Katkısı", ZKÜ Sosyal Bilimler Dergisi, 13 (7), 1-13. 